\title{
MODEL KEPEMIMPINAN TEPAT DALAM MEMPENGARUHI KINERJA DOSEN PERGURUAN TINGGI DI INDONESIA
}

\author{
Tedy Ardiansyah ${ }^{1}$, Dipa Teruna Awaloedin ${ }^{2 *}$ \\ ${ }^{1}$ Fakultas Bahasa dan Seni, Universitas Indraprasta PGRI Jakarta \\ ${ }^{2}$ Program Studi Akuntansi, Fakultas Ekonomi dan Bisnis, Universitas Nasional \\ Jakarta \\ Email : tedyardiansy4h@gmail.com,dipateruna@civitas.unas.ac.id \\ *Korespondensi : dipateruna@civitas.unas.ac.id
}

(Submission 25-03-2021, Revission 29-04-2021, Accepted 03-06-2021)

\begin{abstract}
The purpose of this study is to determine the appropriate form of leadership from various types of leadership on lecturer performance including the correlation results whether the results are significant or insignificant so as to help provide a new literature from current limitations. The research method uses a descriptive qualitative approach, the data used is in the form of secondary data which are all taken from Scopus indexed journals from 2020 to 2017, all journals are in the form of quantitative research and with an average sample of 217 respondents. The conclusion that can be drawn broadly is that existing research creates a new model that not all research related to leadership has a strong influence on lecturer performance, what is unique is that these differences are in the State of Indonesia not in foreign countries, namely Russia, and the type of leadership is only leadership general public that has no relationship with the performance of the lecturers other than that which has a very strong relationship.
\end{abstract}

Keywords: leadership, lecturers performance, leadership model, Indonesia, literature review.

\begin{abstract}
Abstrak
Tujuan dari penelitian ini adalah untuk mengetahui bentuk kepemimpinan yang tepat dari berbagai jenis kepemimpinan terhadap kinerja dosen termasuk hasil korelasi apakah hasil signifikan maupun tidak signifikan sehingga membantu memberikan literatur yang baru dari keterbatasan yang ada saat ini. Metode penelitian menggunakan pendekatan kualitatif deskriptif, Data yang digunakan berupa data sekunder yang semuanya diambil dari jurnal terindeks scopus mulai dari tahun 2020 sampai tahun 2017, semua jurnal berupa penelitian kuantitatif dan dengan sampel rata-rata sebanyak 217 responden. Kesimpulan yang didapatkan secara garis besar adalah penelitian yang ada menimbulkan model baru bahwa tidak semua penelitian yang berhubungan dengan Kepemimpinan mempunyai pengaruh yang kuat terhadap Kinerja dosen, serta jenis kepemimpinan hanya kepemimpinan secara umum yang tidak mempunyai hubungan dengan kinerja dosen selainnya mempunyai hubungan yang sangat kuat.
\end{abstract}


Kata kunci: kepemimpinan, kinerja dosen, model kepemimpinan, Indonesia, kajian literatur.

\section{PENDAHULUAN}

Virus Corona sudah menjadi pandemi penyakit yang menakutkan di dunia saat sekarang ini, termasuk Indonesia. Penyebaran yang sangat cepat itu berdampak sangat besar tentang efek. Indonesia wajib memberikan kebijakan sehingga semua orang mengurangi aktivitasnya atau di rumah hanya jika membutuhkan sesuatu yang dibutuhkan atau mendesak untuk tidak membuat aktivitas yang mengundang kerumunan orang. Pandemi Covid-19 adalah masalah dunia. Berdasarkan data dari Badan Kesehatan Dunia (WHO) pandemi ini telah menjangkau sekitar 215 negara terdampak, di antaranya Indonesia. Perkembangan penyebaran Covid-19 di Indonesia masih meningkat jika dilihat dari kesehariannya data statistik tentang jumlah kasus. Untuk itu, diperlukan upaya membangun kualitas diri di tengah pandemi ini. Selama pandemi ini, dosen tidak mengambil cuti tetapi bekerja dari rumah tanpa ada yang melihat. Sehingga dibutuhkan kesadaran untuk mendisiplinkan diri sendiri. Disiplin adalah pintu masuk ke keberhasilan. Kegiatan kerja harus dilakukan sesuai dengan tetapkan target. Oleh karena itu penyakit menular ini mempunyai efek kematian pada manusia, setiap hari Pemerintah meminta masyarakat tetap aman di rumah untuk menjaga jarak fisik (Jarak Fisik) dan sosial jarak (Social Distancing) bahkan melaksanakan regional karantina (Yunita et al., 2020).

Di dunia yang sangat kompetitif saat ini, organisasi adalah tumbuh secara global dan menghadapi banyak tantangan dalam pencapaiannya tujuan mereka.Dengan begitu, seorang pemimpin diharapkan memainkan sebuah peran penting dalam mencapai tujuan tersebut dan mendorong kinerja karyawan dengan memuaskan pekerjaan mereka (N. G. Torlak et al., 2019). Kualitas seorang pendidik diketahui hal utama dalam mencapai keberhasilan suatu pendidikan proses. Ini karena semua yang dilakukan pendidik akan mempengaruhi prestasi siswa secara akademik dan non akademik (Mahler et al., 2018). Di Selain itu, bagaimana pendidik berkomunikasi juga akan mempengaruhi karakter siswa, atau dengan kata lain kualitas pendidik dapat mempengaruhi kualitas dan hasil belajar. Begitu bahwa mendapatkan kinerja dosen secara tepat sangat penting dalam menentukan kualitas pendidikan di pendidikan yang lebih tinggi. Karena bisa dikatakan semakin baik kualitas kinerja dosen, semakin baik kualitasnya pembelajaran dan prestasi siswa (Sihombing, 2020).

Penggunaan digital teknologi menjadi jawaban yang kini banyak dipilih oleh masyarakat Indonesia dan dunia. Bergantung pada interaksi melalui dunia maya seperti pertemuan online, wisuda online, pembelajaran online, dan semuanya selesai on line. Orang luar negeri yang ingin memanfaatkan kesempatan itu pulang ke rumah untuk berkumpul dengan keluarga mereka tertunda.

Dalam hal ini memanfaatkan aplikasi sebagai metode penyampaian, interaksi, dan fasilitasi. Di dalamnya ada dukungan untuk belajar layanan yang dapat digunakan oleh peserta belajar. Kehadiran teknologi internet mempunyai indikasi untuk terjadinya perubahan gaya hidup manusia dalam berinteraksi dengan dunia 
luar. Seiring perkembangan zaman, kemunculan smartphone atau perangkat pintar berbasis android semakin marak pilihan masyarakat sebagai sarana mengakses internet sebagai pengganti komputer karena mereka punya fitur lengkap. Salah satu "pelajaran" di balik Covid-19 krisis pandemi adalah onlineisasi sebagian besar pendidikan formal kegiatan, termasuk kuliah. Bisa dibilang hampir seratus persen tatap muka perkuliahan berada pada posisi daring, bahkan termasuk ujian akhir di semua jenjang (skripsi, tesis, atau disertasi). Sepertinya tidak berlebihan jika Covid19 telah merevolusi cara belajar. Hal ini dikarenakan tidak hanya mahasiswa yang sudah terbiasa platform digital, tetapi juga generasi senior (generasi $\mathrm{X}$ dan baby boomer) terpaksa menggunakan aplikasi e-learning. Kuliah online memang menawarkan berbagai kemudahan dan kenyamanan. Diantaranya, fleksibilitas dalam ruang (placeless) dan waktu (timeless). Metode upload dan download, perkuliahan di sesuai kebutuhan, dosen dan mahasiswa dapat melakukan keduanya pada waktu yang paling nyaman. Pengecualiannya jika ada aturan atau kesepakatan bahwa perkuliahan dilakukan secara langsung pada waktu tertentu. Akurasi pengukuran kinerja kuantitatif melalui otomatisasi digital berbasis hasil (keluaran). Misalnya materi dan tugas apa yang diposting dan diserahkan, durasi pengajaran, intensitas absensi siswa secara online, hasil kerja siswa (tugas dan ujian) dan lain sebagainya. Semua itu bahkan bisa direkam dengan sempurna diilustrasikan oleh perangkat digital. Ini termasuk memastikan apakah karya dosen dan mahasiswa (khususnya akademik) mengandung plagiat atau tidak.

Kuliah online membuat integrasi dengan dunia internasional lebih mudah dan lebih murah. Kolaborasi dalam banyak hal, seperti penelitian, kerjasama kelembagaan, pertukaran dosen dan penguji (khusus untuk tugas akhir) dengan perguruan tinggi di luar negeri sekaligus bisa menjadi efek domino yang menyertainya. Dosen luar misalnya dapat mengisi kuliah online di kelas tertentu sebagai dosen tamu. Itu hal yang sama bisa dilakukan dalam uji coba ujian akhir. Ini tentu saja bisa menjadi poin tersendiri untuk menaikkan peringkat institusi. Namun, kuliah online juga menghadirkan sejumlah tantangan. Apalagi pola pikir seluruh di perguruan tinggi masih kuat mengandalkan mode konvensional. Ini menyiratkan setidaknya untuk prosedur administratif. Paradigma yang masih melekat kinerja berdasarkan ruang dan waktu yang pasti. Artinya, kehadiran fisik sangat menentukan catatan administrasi. Baik untuk dosen sebagai bukti kehadiran yang menentukan jumlah hak yang diterima, maupun untuk kehadiran mahasiswa yang juga berdampak pada evaluasi penilaian.

Berikutnya adalah pengelolaan infrastruktur yang belum akrab dengan mode online. Tidak sedikit kasus dimana keluhan dosen dan mahasiswa. Ini karena ketersediaan jaringan internet yang sering kurang memadai, kuota yang besar sehingga kurang bersahabat dengan kantong mahasiswa, platform berbeda yang digunakan antar dosen, sehingga menyulitkan bagi institusi untuk mengelola dan mahasiswa untuk mengakses perkuliahan, ke tingkat kemampuan untuk mengoperasikan perangkat digital yang berbeda. Menariknya, krisis pandemi telah memaksa semua itu hal-hal yang difokuskan untuk diselesaikan dengan segera. Beberapa institusi bahkan mengeluarkan kebijakan afirmatif berupa bantuan kuota untuk dosen dan mahasiswa, platform seragam untuk pelatihan kecelakaan 
mengoperasikan perangkat lunak yang diperlukan. Memang, arus utama asumsi menganggap bahwa kuliah online lebih efisien. Namun, ini mungkin berlaku jika dilakukan secara menyeluruh. Artinya, dengan menghilangkan perkuliahan konvensional sama sekali. Ia akan memangkas berbagai biaya yang terdapat pada moda konvensional, seperti biaya asrama mahasiswa, biaya pemeliharaan gedung lembaga, biaya personel cleaning service, transportasi biaya ke kampus setiap hari, dan sebagainya. Sementara itu menggabungkan kursus konvensional dan online ada yang besar kemungkinan pembiayaan akan berlipat ganda. Ini karena pembiayaan perkuliahan konvensional tetap berlaku ditambah dengan pembiayaan perkuliahan online seperti biaya pembelian platform untuk institusi, biaya kuota internet, memadai biaya smartphone, dan sebagainya. Terakhir, substantif tantangan berupa tujuan pembelajaran, khususnya itu terkait dengan pembangunan karakter dan sisi manusia. Online perkuliahan, dalam pengalaman beberapa orang, terasa tidak memadai menampung ini. Memang, pertemuan virtual telah memaksa orang untuk diam dan membuang waktu. Namun, efek sampingnya adalah bahwa hubungan tersebut cenderung mekanistik dan tidak terlalu emosional. Mahasiswa dan dosen dapat melaksanakannya berfungsi hanya untuk membatalkan kewajiban. Tidak banyak melibatkan aspek afektif atau psikomotorik. Ini pasti membuatnya sulit misalnya bagaimana melatih ketrampilan siswa dalam menghadapi masyarakat atau hidup dalam masyarakat.

Dalam sepuluh tahun terakhir, universitas telah menjadi fundamental perubahan dalam pengembangan kurikulum, serta peran dosen dan strategi pembelajaran (Noor et al., 2020). Perubahan tersebut membawa perubahan filosofi itu menguasai era pemimpin yang hebat. Kepemimpinan menurut Rusydi (2017) dapat berpengaruh signifikan terhadap kinerja dosen di perguruan tinggi. Menurut Masa'deh et al. (2016) juga diketahui hal itu gaya kepemimpinan merupakan faktor strategis yang dapat mempengaruhi inovasi dan berbagi pengetahuan karena pemimpin bisa memungkinkan organisasi untuk mengintegrasikan, berbagi, dan menggunakan pengetahuan dengan cara yang inovatif. Selain itu, kinerja dianggap sebagai variabel penting dalam literatur Manajemen Sumber Daya Manusia (MSDM) dan perilaku organisasi, yang selanjutnya terkait dengan operasi organisasi.

Karena orang akan berinvestasi dalam organisasi untuk mencapai tujuan, setiap upaya dilakukan untuk memastikan bahwa mereka melakukan yang terbaik mencapai tujuan tersebut. Faktanya adalah bahwa karyawan membutuhkan ekstra dorongan untuk membuat mereka tetap tertarik, antusias, dan bangga. Menurut Masa'deh et al. (2016) kepemimpinan bisa diintegrasikan secara proporsional, yaitu antara kepemimpinan transaksional dan transformasional yang akan memotivasi dosen untuk secara sadar dan profesional menjalankannya tugas-tugas yang melebihi standar kinerja yang diharapkan. Pemimpin transaksional memahami untuk kebutuhan dan keinginan bawahan mereka. Karena dalam hal ini hubungan kepemimpinan transaksional, pemimpin akan memberi bawahannya pengembalian kinerja yang layak. Oleh karena itu, kepemimpinan transaksional adalah salah satu jenis kepemimpinan yang dapat mendorong bawahan untuk menyediakan semua keterampilan untuk mencapai hasil terbaik bagi organisasi. Selain dari 
kepemimpinan transaksional, beberapa transformasional pemimpin dapat mempengaruhi satu atau lebih orang di organisasi. Kepemimpinan transformasional didasarkan pada prinsip-prinsip yang terkait dengan pengembangan bawahan proses. Pemimpin transformasional mengevaluasi semua kemampuan dan potensi setiap bawahan untuk menjalankan pekerjaannya, dengan melihat kemungkinan perluasan dan pemberdayaan bawahan di masa depan (Bastari et al., 2020). Di dalam jenis organisasi, dua pemimpin memiliki pandangan yang sama memberikan kepemimpinan kepada bawahan mereka. Transaksional pemimpin akan menjelaskan Term \& Conditions pengikut menuju tujuan yang ditetapkan, sambil transformasional pemimpin akan menginspirasi pengikutnya untuk melampaui kepribadian mereka kepentingan untuk kebaikan organisasi (Olabanji et al., 2016).

Terlepas dari gaya kepemimpinan dan kinerja dosen, faktor lainnya berupa kepuasan kerja. Greenberg seperti dikutip Anwar et al. (2017) kepuasan kerja merupakan sekumpulan perasaan karyawan senang atau tidak senang berhubungan dengan pekerjaan mereka. Atau pekerjaan kepuasan dinyatakan sebagai tingkat perasaan orang mengenai pekerjaan mereka. Itu emosional menanggapi tugas seseorang, serta fisik dan sosial kondisi di tempat kerja. Karyawan dengan pekerjaan tingkat tinggi kepuasan menunjukkan sikap positif terhadap pekerjaannya (Syabarrudin et al., 2020). Peran pemimpin adalah kepuasan kerja dan kinerja. Penelitian ilmiah tentang masalah kepemimpinan biasanya menunjukkan hal itu kepuasan dan kinerja adalah hal-hal yang menjadi kepemimpinan bisa menginspirasi.

Bagaimana dosen memahami kepemimpinannya? Apakah mereka berpikir dia sebagai pemimpin? Bagaimana hubungan dengan kinerja dosen? Para riset telah memberikan gambaran antara gaya kepemimpinan universitas, kepuasan dan kinerja dosen (Purwanto et al., 2020). Tujuan dari penelitian ini adalah untuk mengetahui bentuk kepemimpinan yang tepat dari beberapa jenis kepemimpinan terhadap kinerja dosen beserta hubungannya baik secara signifikan maupun tidak signifikan sehingga membantu memberikan literatur yang baru dari keterbatasan yang ada pada saat sekarang ini.

\section{METODE}

Metode yang digunakan dalam riset ini adalah deskriptif kualitatif, biasanya desain deskriptif kualitatif bersifat pilihan tetapi masuk akal dan dipertimbangkan dengan baik kombinasi pengambilan sampel, dan pengumpulan data, analisis, dan teknik representasi. Pada bagian berikut, menjelaskan desain tipikal fitur. Deskripsi kualitatif khususnya setuju untuk mendapatkan lurus dan sebagian besar tanpa hiasan (yaitu, minimal berteori atau sebaliknya ditransformasikan atau berputar) jawaban atas pertanyaan relevansi khusus dengan praktisi dan kebijakan pembuat (Sandelowski, 2000).

Data yang digunakan berupa data sekunder yang semuanya diambil dari jurnal terindeks scopus mulai dari tahun 2020 sampai tahun 2017, dimana publishernya antara lain: EManuscript Technologies, SAGE Publications, Sciedu Press, institute of Advanced Scientific Research, Innovare Academics Sciences, International Journal of Scientific and Technology Research, Primrose Hall 
Publishing Group, SRAC - Romanian Society for Quality, Serials Publications, National Research University, Higher School of Econoimics, American Scientific Publishers.

Berbagai pedoman telah disarankan untuk validasi penelitian kualitatif. Ini dapat dibagi menjadi dua kelompok dasar: ekstrinsik (berdasarkan kriteria yang diimpor dari penelitian kuantitatif dan disesuaikan dengan penelitian kualitatif) dan intrinsik (berdasarkan konteks penelitian kualitatif). Telah diperdebatkan bahwa opsi kedua lebih disukai karena ini adalah cara untuk meningkatkan kredibilitas penelitian kualitatif (Morrow, 2015). Penilaian pengetahuan ilmiah melibatkan tiga konsep utama, yaitu validasi, reliabilitas, dan generalisasi. Sebuah saran dibuat untuk penelitian kualitatif untuk menekankan pengertian tentang kepercayaan dari metode, koherensi hasil, dan pengalihan dan penerapan hasil (Hill, Thompson, \& Williams, 1997; Lincoln \& Guba, 1985).

Peneliti kualitatif sekarang memiliki pilihan untuk memilih dari suatu kelompok yang meningkat secara teoritis dan metode yang secara teknis canggih. Oleh karena itu, mungkin tampak aneh untuk menghidupkan kembali yang lebih sederhana dan banyak metode yaitu, deskripsi kualitatif. Namun justru itu meningkatnya kompleksitas metode kualitatif dan tirani metode dalam penelitian sehingga membuat penemuan kembali melalui deskripsi kualitatif sangat diperlukan.

Penelitian deskriptif biasanya digambarkan dalam teks penelitian berada di anak tangga terbawah dari hirarki desain penelitian kuantitatif. Dalam literatur metode kualitatif yang sekarang luas, tidak ada deskripsi yang komprehensif tentang deskripsi kualitatif sebagai metode khas yang setara berdiri dengan metode kualitatif lain, meskipun itu adalah salah satu yang paling sering digunakan pendekatan metodologis dalam disiplin praktek.

\section{HASIL DAN PEMBAHASAN Hasil Penelitian}

Beberapa hasil penelitan yang mendukung dari variabel penelitian dan kinerja dosen diperguruan tinggi di Indonesia adalah sebagai berikut:

\section{Kepemimpinan Transaksional}

Kepemimpinan transaksional didasarkan pada asumsi itu, karyawan dimotivasi oleh penghargaan dan hukuman. Menurut Zainuddin et al., (2019), transaksional kepemimpinan paling cocok untuk sistem sosial yang bekerja paling baik melalui rantai komando yang jelas. Karena dalam konsep ini tanggung jawab utama karyawan adalah melakukan apa yang mereka lakukan atasan menyuruh mereka melakukannya. Dengan begitu, transaksional kepemimpinan juga bisa dikatakan otokratis karena pemimpin mengharapkan bawahannya untuk mematuhi yang ditetapkan aturan dan ikuti instruksi dari pemimpin. Berdasarkan Bass dikutip oleh (Mustika et al., 2020), konsep awal kepemimpinan transaksional akan menjelaskan proses dari kebutuhan bawahan yang harus dipenuhi dengan imbalan peran pemimpin, dan bahwa pemimpin hanya dapat bereaksi jika bawahan gagal memenuhi kebutuhan peran mereka. Transaksional kepemimpinan juga dapat didefinisikan sebagai aktivitas yang memandu bawahan ke tujuan yang telah 
ditentukan dengan menekankan peran dan tugas tersebut (Wahyuni \& Eliyana, 2014). Robbin \& Judge (2008) menyatakan bahwa ada persyaratan dalam kepemimpinan transaksional, yaitu penghargaan bersyarat, manajemen dengan pengecualian (pasif) dan manajemen oleh pengecualian (aktif).

\section{Kepemimpinan Transformasional}

Konsep kepemimpinan transformasional sudah dimulai secara bertahap menggeser konsep kepemimpinan instruksional, sebagai harapan di dunia pendidikan untuk pendidikan tinggi pemimpin untuk membawa tipe kepemimpinan visioner ke dalam organisasi (Noor Azizah et al., 2020). Transformasional kepemimpinan adalah salah satu teori paling populer di lapangan kepemimpinan dan telah dianggap sebagai topik penting terkait dengan kepemimpinan selama lebih dari 20 tahun (Long et al., 2014). Minat ini karena transformasional kepemimpinan mengarah pada hubungan yang positif dan superior dengan bawahan, komitmen, motivasi kinerja, dan pemimpin yang efektif (Masa'deh et al., 2016). Transformasional kepemimpinan didasarkan pada prinsip-prinsip yang terkait dengan proses pengembangan bawahan. Transformasional pemimpin mengevaluasi semua kemampuan dan potensi masing-masing bawahan untuk melaksanakan pekerjaan mereka, dengan melihat kemungkinan memperluas dan memberdayakan bawahan dalam masa depan (Bastari et al., 2020). Pemimpin transformasional juga dikenal mampu mengubah organisasi dengan mengidentifikasi kebutuhan akan perubahan, memulai sebuah visi, dan memobilisasi komitmen untuk mewujudkan visi itu (Manurung, 2020).

\section{Kinerja Dosen}

Salbiyah et al, (2019) menyatakan bahwa tentang kinerja dan tanggung jawab dosen dalam menjalankan tugas profesionalnya, kinerja dosennya tertuang dalam Undang-Undang Nomor 14 Tahun 2005, yaitu: Pembawaan keluar dari pendidikan, penelitian, dan pengabdian masyarakat, merencanakan, melaksanakan proses pembelajaran, dan menilai dan mengevaluasi hasil belajar; Lanjutkan untuk meningkatkan dan mengembangkan kualifikasi akademik dan kompetensi; Bertindak obyektif dan non-diskriminatif berdasarkan pertimbangan jenis kelamin siswa, agama, suku, ras, fisik tertentu kondisi, atau latar belakang sosial ekonomi dalam pembelajaran; Menjunjung tinggi peraturan perundang-undangan, hukum, dan kode etik, seperti serta nilai-nilai agama dan etika; dan memelihara dan membina persatuan dan kesatuan nasional. Menurut seorang artikel yang dimuat di Buletin (Direktorat Pendidik \& Pendidikan, Direktorat Jenderal Pendidikan Tinggi, 2014), disebutkan bahwa dosen yang meneliti publikasi karya ilmiah merupakan salah satu upaya untuk meningkatkan kinerja para dosen tersebut. Performa didefinisikan sebagai hasil penyelesaian pekerjaan yang mewakili tingkat pencapaian seseorang di setiap pekerjaan dan dalam memenuhi kebijakan, harapan, atau persyaratan untuk peran resmi organisasi (Wardani \& Eliyana, 2020). Kinerja juga dapat diartikan sebagai produktivitas yang menyatakan kualitas, kuantitas, dan kontribusi pekerjaan, ketika produktivitas tinggi, kinerja keseluruhan di organisasi juga akan tinggi. 


\section{PEMBAHASAN PENELITIAN}

Dari hasil penelitian diatas beberapa penelitian ada yang menyatakan pada kepemimpinan transformational, ada pula kepemimpinan transaksional ataupun kedua-duanya terhadap kinerja dosen.

Hasil penelitian ini menyimpulkan bahwa transformasional kepemimpinan berpengaruh positif dan signifikan terhadap perguruan tinggi Islam. Kepuasan dosen, kepemimpinan transaksional tidak berpengaruh signifikan terhadap kepuasan dosen universitas Islam. Penelitian baru ini mengusulkan model untuk membangun kepuasan kerja bagi dosen universitas Islam di Jakarta melalui peningkatan kepemimpinan transformasional (Yunita et al., 2020). Berdasarkan analisis yang telah dilakukan maka dapat dikatakan menyimpulkan dalam penelitian ini bahwa kepemimpinan transaksional memiliki berpengaruh signifikan terhadap kinerja bagi dosen, kepemimpinan transformasional memiliki pengaruh yang signifikan berpengaruh terhadap kinerja dosen (Angriani et al., 2020). Dengan menggunakan analisis jalur Lisrel 8.80 maka dapat disimpulkan bahwa: (1) terdapat pengaruh yang signifikan variabel reward tentang kinerja dosen di Perguruan Tinggi Agama Budha Indonesia; (2) variabel kepemimpinan tidak berpengaruh signifikan tentang kinerja dosen di Perguruan Tinggi Agama Budha Indonesia (Sugiharto, 2020). Berdasarkan uraian sebelumnya, dapat disimpulkan bahwa kepemimpinan dekan searah positif berpengaruh terhadap kinerja dosen. Nilai kontribusi langsung dari kepemimpinan dekan kinerja dosen sebesar 0,223 atau 4,97\% (Feliks, Ambarita, \& Nasution, 2019). Berdasarkan hasil di atas dapat disimpulkan bahwa: 1. Bersamaan dengan motivasi, lingkungan kerja, dan kepemimpinan diri berpengaruh signifikan terhadap kinerja dosen di Politeknik Negeri jember. 2. Secara parsial motivasi, lingkungan kerja, dan kepemimpinan diri berpengaruh signifikan terhadap dosen pertunjukan di Politeknik Negeri Jember (Kurniawati, 2019). Hasil penelitian menunjukkan bahwa: pertama, terdapat pengaruh langsung budaya organisasi terhadap kinerja; kedua, disana adalah efek langsung dari kepemimpinan terhadap kinerja; ketiga, ada pengaruh langsung motivasi berprestasi pada kinerja; keempat, ada pengaruh langsung dari budaya organisasi terhadap motivasi berprestasi; kelima, ada pengaruh langsung kepemimpinan terhadap prestasi motivasi. Implikasi dari penelitian ini adalah bahwa upaya untuk meningkatkan kinerja dosen dapat dilakukan dengan meningkatkan budaya organisasi, kepemimpinan, dan motivasi berprestasi (Anra \& Yamin, 2017). Penelitian ini melahirkan konsep baru tentang kinerja pembelajaran dosen. Pengaruh kepemimpinan kualitas pengetahuan, kompetensi osen, dan kerja cerdas terhadap prestasi belajar dosen. kepemimpinan altruistik partisipatif diharapkan mampu menciptakan kondisi yang kondusif bagi kinerja pembelajaran dosen (Handayani, Sugiharto, \& Sutarto, 2020). Hasil penelitian menunjukkan bahwa kepemimpinan, kompetensi dan motivasi berpengaruh positif terhadap peningkatan kinerja (Rahardja, Raharja, Lutfiani, \& Raharja, 97AD).

\section{SIMPULAN}

Berdasarkan dari hasil dan pembahasan dapat disimpulan untuk hubungan antara kepemimpinan dan kinerja dosen sebagai berikut: 
1. Seluruh data diambil dari penelitian kuantitatif yang mana terindeks jurnal internasional bereputasi, dimana hasil yang di kemukakan bersifat tepat dan akurat, sampel diambil dari dua negara yaitu dari Indonesia dan Rusia, namun secara mayoritas lebih banyak di Indonesia.

2. Dari penelitian yang ada menimbulkan model kepemimpinan baru bahwa tidak semua penelitian yang berhubungan dengan kepemimpinan mempunyai pengaruh yang kuat terhadap kinerja dosen, yang uniknya perbedaan tersebut berada di negara Indonesia bukan di negara luar yaitu Rusia.

3. Sampel yang diambil berkisar antara 30 sampai kurang lebih 800 dosen, dimana sampel yang terkecil adalah 38 dosen dan yang paling terbesar adalah 706 dosen, dimana rata-rata untuk sampel adalah 217.5, sedangkan kepemimpinan tidak mempunyai hubungan dengan kinerja dosen pada sampel 200 responden.

4. Kepemimpinan dari data riset penelitian sebelumnya terbagi menjadi tiga yaitu kepemimpinan secara umum, kepemimpinan transactional dan kepemimpinan transformational.

5. Dari tiga (3) jenis kepemimpinan hanya kepemimpinan secara umum yang tidak mempunyai hubungan dengan kinerja dosen selainnya mempunyai hubungan yang sangat kuat.

\section{DAFTAR PUSTAKA}

A. Syabarrudin, Eliyana, A., \& Naimah, J. (2020). Does employees' self-efficacy drive their organizational commitment? Systematic Reviews in Pharmacy, 11(4), 135-141. https://doi.org/https://doi.org/10.31838/srp.2020.4.21.

Angriani, M. R., Eliyana, A., Fitrah, H., \& Sembodo, P. (2020). The Effect of Transactional and Transformational Leadership on Lecturer Performance with Job Satisfaction as the Mediation. Sys Rev Pharm, 11(11), 1263-1272.

Anra, Y., \& Yamin, M. (2017). Relationships between Lecturer Performance, Organizational Culture, Leadership, and Achievement Motivation. Foresight and STI Governance, 11(2). https://doi.org/10.17323/25002597.2017.2.92.97.

Anwar, M., G., C., Darsono, J. T., \& Respati, H. (2017). Lecturer Job Performance Study: Motivation, Emotional Intelligence, Organizational Culture, and Transformational Leadership as Antecedents with Job Satisfaction as an Intervening. IOSR Journal of Business and Management, 19(06), 01-09. https://doi.org/https://doi.org/10.9790/487x-1906020109.

Bastari, A., Eliyana, A., \& Wijayanti, T. (2020). Effects of transformational leadership styles on job performance with job motivation as mediation: A study in a state-owned enterprise. Management Science Letters, 10(12), 
2883-2888. https://doi.org/https://doi.org/10.5267/j.msl.2020.4.019.

Feliks, D., Ambarita, P., \& Nasution, N. B. (2019). The Effect of Dean Leadership , on the Performance of Lecturers Working in The Faculty of Education in Medan State University, 5(5), 515-530.

Handayani, S., Sugiharto, D. Y. P., \& Sutarto, J. (2020). The Role of Smart Working in Mediating Participatory Altruistic Leadership , Competence , Quality knowledge in Learning Performance of Lecturers in Higher Education, 9(5), 346-352. https://doi.org/10.5430/ijhe.v9n5p346.

Hill, C., Thompson, B., \& Williams, B. (1997). 'A guide to conducting consensual qualitative research.' The Counselling Psychologist, 25(4), 517-572.

Kurniawati, D. (2019). The effect of motivation, working environment, and self leadership on lecturer performance at politeknik negeri jember. International Journal of Scientific and Technology Research, 8(7), 820-825. Retrieved from https://www.scopus.com/inward/record.uri?partnerID=HzOxMe3b\&scp=85 071371991\&origin=inward.

Lincoln, Y., \& Guba, E. (1985). Naturalistic inquiry. London: Sage Publication.

Mahler, D., Großschedl, J., \& Harms, U. (2018). Does motivation matter? - The relationship between teachers' self-efficacy and enthusiasm and students' performance. $P L o S$

ONE. https://doi.org/https://doi.org/10.1371/journal.pone.0207252.

Masa'deh, R., Obeidat, B. Y., \& Tarhini, A. (2016). A Jordanian empirical study of the associations among transformational leadership, transactional leadership, knowledge sharing, job performance, and firm performance: A structural equation modeling approach. Journal of Management Development, 35(5), 681-705. https://doi.org/https://doi.org/10.1108/JMD-09-2015- 0134.

Morrow, S. L. (2015). 'Quality and trustworthiness in qualitative research in counselling psychology',. Journal of Counselling Psychology, 52(2), 250260.

N. G. Torlak, \& Kuzey, C. (2019). Leadership, job satisfaction, and performance links in private education institutes of Pakistan. International Journal of Productivity and Performance Management, 68(2), 276-295. https://doi.org/https://doi.org/10.1108/IJPPM-05-2018- 0182.

Noor, Y. A., Rijal, K. M., Rohmah, N. U., Pranajaya, S. A., Ngiu, Z., Mufid, A., ... HaliahMàu, D. (2020). Transformational or Transactional Leadership Style: 
Which Affects Work Satisfaction and Performance of Islamic University Lecturers During COVID-19 Pandemic? Systematic Reviews in Pharmacy, 11(7), 577-588.

Olabanji, O. E., \& Abayomi, A. A. (2016). Influence of Transformational and Transactional Leadership on Motivation of Academic Staff in Nigerian Universities. Islamic University Multidisciplinary Journal (IUMJ), 123-128.

Purwanto, A., Wijayanti, L. M., Hyun, C. C., \& Asbari, M. (2020). the Effect of Tansformational, Transactional, Authentic, and Authoritarian Leadership Style Toward Lecture Performance of Private University in Tangerang. Dinasti International Journal of Digital Business Management, 1(1), 29-42. https://doi.org/https://doi.org/10.31933/dijdbm.v1i1.88.

Rahardja, U., Raharja, U., Lutfiani, N., \& Raharja, U. (97AD). LEADERSHIP , Competency , Working Motivation And Performance Of High Private Education Lecturer With Institution Accreditation B: Area Kopertis Iv Banten Province And Performance Of High Private Education Lecturer With Institution Accreditation B : Man in India, 24(24), 179-192.

Rusydi, M. (2017). The Role of Leadership in Supporting the Competence and Achievements of the Lecturers Kopertis Region Ix City of Makassar. Review of European Studies, 170. https://doi.org/https://doi.org/10.5539/res.v9n4p170.

Sandelowski, M. (2000). Focus on Research Methods Whatever Happened to Qualitative Description? ResearchinNursing \&Health, (23), 334-340.

Sihombing, M. (2020). The Effect of Transformational Leadership, Work Discipline, and Satisfaction on Lecturers' Performance at the Tarbiyah and Teaching Faculty of UIN Antasari Banjarmasin. Journal of K6 Education and Management, 3(2), 100-108. https://doi.org/https://doi.org/10.11594/jk6em.03.02.01.

Sugiharto, Y. P. (2020). Influence Of Reward, Leadership , And Organizational Culture To Lecturer Performance Of Indonesia Buddhis Religious College, 7(7), 449-455.

Yunita Noor Azizaha, Muhammad Khairul Rijalb, R., Umi Nuriyatur Rohmahd, S. A. P., Ngiuf, Z., Mufidg, A., Purwantoh, A., \& Ma`u, D. H. (2020). Transformational or Transactional Leadership Style: Which Affects Work Satisfaction and Performance of Islamic University Lecturers During COVID-19 Pandemic ?, 11(7), 577-588. 